\title{
Harnessing the potential of extracurricular opportunities to enhance graduate employability in higher education
}

\author{
Maria Moxey \\ University of Winchester \\ Edward Simpkin \\ University of Winchester
}

\section{Abstract}

This paper addresses the emerging theme in the literature that graduates often do not demonstrate the relevant skills to employers in job applications, interviews and in the workplace, and that HEls should harness the potential of extra-curricular opportunities to enhance employability (Tchibozo, 2007; Griffiths et al., 2017). This study reports on a survey which was distributed to students in voluntary committee roles at one university to garner information around students' ability to identify the skills gained in their roles that are transferable as employability skills. The students' level of confidence and readiness to articulate these skills during the job application process was then explored. Results suggest that, while students feel as though they are confident and ready to draw on skills developed in extra-curricular voluntary roles, questions could be raised as to whether their ability to identify and articulate them accurately reflects their level of confidence. Therefore, a workshop and resource have been created as part of the project to help students be able to recognise and articulate the employability skills gained.

Keywords: Extra-curricular activities; employability; leadership; skills; higher education.

\section{Introduction}

It has become increasingly important, since the turn of the century, that students are employable when they leave university (Allen et al., 2013; Tymon, 2013; Griffiths et al., 2017). As the pressure for outcomes increases, tuition fees continue to rise across 
western higher education ( $\mathrm{HE})$, and universities are seen as marketised entities, the issue of graduate employability has become more pressing (Milburn-Shaw and Walker 2017; Donald et al., 2018). Consequently, universities are exploring ways to enhance student employability and prepare students for the workplace within and outside the curriculum. While it is widely accepted that extracurricular activities (ECAs) enhance the student experience, and there is a growing body of literature on their role in aiding the socialisation process and fostering a sense of belonging at university (Tieu et al., 2010), their value in enhancing employability is less well-documented (Winstone et al., 2020). The literature that does exist indicates that ECAs can be beneficial for social networking, developing skills and improving employability (Stevenson and Clegg, 2011; Clark et al., 2015). ECAs in $\mathrm{HE}$ are defined as informal spaces which allow for 'life-wide learning' within the student experience and which are not part of the formal degree classification (Jackson, 2011; Thompson et al., 2013). In this paper, when referring to ECAs, the authors are predominantly referring to societies, clubs and voluntary roles and not to activities such as placements, part-time jobs or studying abroad.

Universities have a wide variety of ECAs on offer, including sports clubs, societies, and network groups, most of which are student-led and offer voluntary opportunities such as captain, vice-captain, social secretary and wellbeing officer (Thompson et al., 2013). The literature suggests that volunteering in leadership or committee roles in sports teams and societies can enhance employability, yet studies continue to report that many graduates do not possess the necessary skills for the modern workplace (Bowers-Brown and Harvey, 2004; Heaton et al., 2008; Cumming, 2010; Lowden et al., 2011; Gedye and Beaumont, 2018; Prospects, 2018; Teng et al., 2019). While students recognise leadership positions can be valuable for employability, evidence suggests they often do not demonstrate the relevant skills to employers in job applications, interviews and in the workplace itself (Frankham, 2017). Therefore, this paper hopes to address this by enabling students at this university to harness the transferable skills gained through voluntary leadership positions.

\section{Defining employability}

When defining employability, there are different stakeholder perspectives to consider, such as the government, employers, HEls, students and graduates (Tymon, 2013). Since these 
parties have different priorities and drivers in relation to graduate employability, agreeing on one definition can be challenging. Nevertheless, it is commonly accepted that values, attitudes, behaviours and competencies should be incorporated, and therefore the following definitions are useful:

Employability means that students and graduates can discern, acquire, adapt and continually enhance the skills, understandings and personal attributes that make them more likely to find and create meaningful paid and unpaid work that benefits themselves, the workforce, the community and the economy (Oliver, 2015, p.63).

The capability of obtaining work, functioning effectively within work; moving between jobs/roles; and having the skills, knowledge and attributes that make this possible (Gedye and Beaumont, 2018, p.408).

Oliver's (2015) definition accounts for the journey that students and graduates undertake to develop personal and professional attributes to help find meaningful employment. Gedye and Beaumont's (2018) conceptualisation of employability is particularly useful, as they consider personal factors such as self-efficacy, self-confidence, and self-esteem as moderators for employability, which are helpful when considering students' readiness to apply for jobs relating to their chosen career paths.

\section{Contextualising employability and higher education in the UK}

There are several factors that have contributed towards graduate employability becoming a priority across the $\mathrm{HE}$ sector, not least the precarious nature of the economy leading to higher unemployment rates and reduced job security (Griffiths et al., 2017). As universities have become more accessible (McCaig, 2011), the number of graduates competing for jobs has increased; thus, many graduates are overeducated for their first jobs and do not directly utilise the academic content of their degree (Griffiths et al., 2017).

Under the Further Education Act 1992, polytechnic universities were able to offer accredited degrees, and during the following twenty years, annual tuition fees increased. As tuition fees have increased, so has the pressure on institutions to deliver a better 
university experience, as well as ensure social mobility and employability (Milburn-Shaw and Walker, 2017). With the introduction of the Teaching Excellence and Student Outcomes Framework, and continued emphasis on student outcomes in a marketised education, universities have had to become more accountable for their performance and the service they provide, which has led to increased importance placed on measuring institutional performance through quality assurance, league tables and the National Student Satisfaction survey (Office for Students, 2020). League table position is a key indicator of performance in terms of university recruitment, reputation, and employability (Frankham, 2017).

Not only is graduate employment becoming more competitive, but graduates are seemingly underprepared for the world of work, particularly lacking soft skills (Tchibozo, 2007; Teng et al., 2019). Cumming (2010, p.3) notes that 'a dominant theme emerging is that many graduates lack appropriate skills, attitudes and dispositions, which in turn prevents them from participating effectively in the workplace'. Indeed, employers have been raising concerns about the quality of graduates for the last three decades and continue to put pressure on universities to deliver work-ready employees (Tymon, 2013; Clarke, 2018).

Employers expect graduates to have the requisite technical and discipline competencies from their degrees and require them to demonstrate a range of broader skills and attributes that include teamwork, communication, leadership, critical thinking, problem solving and often managerial abilities or potential (Allen et al., 2013). Branine (2008) found that graduate employers are more interested in personal attributes and soft skills than degree classifications, subject, or which university students attended. This demonstrates that employers value transferable skills which are often developed outside the classroom as well as in it.

It is evident that employers value someone who has participated in ECA whilst at university, with particular emphasis on those who took up roles of leadership or responsibility. Allen et al. (2013) state that employers were overwhelmingly positive about the benefits of graduates having engaged in sport whilst at university and the skills and attributes they develop. Additionally, employers consider leadership positions, organisational roles, and other positions of responsibility within sports clubs and societies 
to be particularly beneficial in providing 'added value' (Allen et al., 2013). However, it is not enough for graduates to simply list these activities on an application form; employers are looking for graduates who are able to demonstrate why these attributes are important and how they can be utilised in the workplace (Allen et al., 2013).

Students are also becoming increasingly aware of the value of participating in activities outside of the classroom (Thompson et al., 2013). In research undertaken to explore student perceptions of learning experiences, when asked to outline eight of their most significant learning experiences, $52 \%$ of the experiences described were co-curricular (Lackner and Martini, 2017). Additionally, Clark et al. (2015) found that, in the opinion of graduates, ECA significantly helped develop employability skills, contributed to their first employment, and enhanced their workplace performance, again demonstrating that there is a prevalent view amongst current students and graduates that ECA increases employability. Despite this, Tymon (2013) found, when students were asked about how employability could be developed at university, that ECAs were only identified as valuable by a small minority of the students in the sample. This demonstrates that the value of ECA amongst students is unclear and multifaceted, and needs further research.

There is an expectation from the government and employers that HEls have a responsibility to prepare graduates for work (Tymon, 2013). Whilst HEls cannot be solely accountable for solving this issue, employer dissatisfaction with the attributes of the individuals they recruit from universities cannot be ignored (Hesketh, 2000). A solution would be to have a more joined up approach in which more interaction and meaningful discussion exists between employers and HEls about how to get students engaging with employability and ready for work. While this issue needs further consideration in future research, the aim of this paper is to take responsibility as an $\mathrm{HEl}$ and consider the extent to which students can harness the potential of existing ECA opportunities at this university to help develop and demonstrate their employability.

\section{Research method}

For this small-scale study, a survey was distributed to all students at the university who held positions of responsibility in sports teams, societies and network groups. The survey 
was distributed via the Student Union's volunteer contact database, and of the 200 students who were invited to participate, 12 undergraduates responded. The survey sought to gather information around motivations for volunteering in roles of responsibility, and to gauge their confidence and readiness to apply skills gained in these roles to the context of employability. The survey questions were as follows:

1. Please select whether you are member of a Sports Team Committee, Society Committee or Network Committee.

2. What is your leadership role in your society, sports team or network (e.g. captain, chair, social secretary etc.)?

3. Why did you run for your role within the society or sports team? Please describe your aim and motivation.

4. What skills do you think you have or will have acquired through your role?

5. When you apply for jobs, how confident will you be in explaining your role and skill set gained?

6. What can the university do to help you communicate your leadership role in job interviews or applications? (We really want to know how we can help with your future, so please let us know any ideas you may have).

The survey used a combination of quantitative and qualitative questions to obtain information about the participants' backgrounds in relation to the research question, as well as more detailed responses when required (Fowler, 2014). The first two questions were quantitative, and allowed participants to provide contextual information, for example, whether they were in a sports team, society or network group, as well as their role within these groups, and students could select multiple answers if applicable. Question 5 utilised a Likert scale of responses from 'completely confident' to 'not confident at all'. Whilst this question was controlled, it did have some flexibility as it enabled the students to place on a scale how confident they felt.

Qualitative questions 3, 4 and 6 allowed for in-depth answers via a textbox without providing any choices, giving participants the opportunity to write freely. These questions were intended to garner information around motivations for volunteering in roles of responsibility and to discern whether this was something they saw as valuable that they could use in job applications, CVs and job interviews. Question 4 explored participants' 
ability to identify skills gained and why they are applicable to employment, while question 6 requested feedback about how the university could help students develop employability. As the research used human participants, it was important to account for key ethical considerations to minimise potential harm. The research received ethical clearance from the university where the research took place, demonstrating that ethical considerations such as preserving confidentiality, informed consent and data protection guidelines have been sufficiently accounted for (Christians, 2011).

\section{Data analysis and research limitations}

A rigorous approach was taken to analysing the results from the survey. Quantitative questions 1 and 5 were analysed based on frequency of occurrence to identify the number of respondents in sports teams, societies and network groups, and their perceived level of confidence. Thematic analysis was employed to draw findings from qualitative questions 3 , 4 and 6. Dominant themes emerged based on frequency of occurrence or if deemed significant based on researcher interpretation and connection to the literature (Braun and Clarke, 2012). From this, it was possible to draw conclusions around students' motivations for volunteering in leadership roles, and the employability skills they believe they developed in these positions. The reliability of findings drawn from thematic analysis was ensured through investigator triangulation whereby a second researcher offered a different theoretical perspective, to challenge or corroborate themes (Flick, 2007).

It should be acknowledged that for question 4, while some participants listed skills gained in leadership positions, such as communication for example, others expanded on the term and gave more detail about the way they used their communication skills in the context of their role. The researchers interpreted this to demonstrate that the respondent understood how this skill is relevant to their role, suggesting that they would be able to articulate this to a potential employer. Whilst students were not asked to write an exhaustive list of skills accrued and expand on them as if they were writing a job application, the number of skills identified, and their ability to support the skill with some explanation of how it relates to an employment context, allowed the researcher to draw inferences around participants' ability to do so. 
A survey was deemed an appropriate method for collecting data in this research as time and resources were limited, and surveys are an efficient way of collating data from many participants (Fowler, 2014). Also, with the study taking place during the Covid-19 pandemic, this allowed participants the flexibility to complete the short survey digitally at a time that suited them. With more time and resources, it would be valuable to hold follow-up focus groups with participants to expand on and add context to their survey responses (Creswell and Clark, 2018). This would provide the opportunity to garner rich and detailed information about their motivations for volunteering, as well as their awareness of skills accrued from ECA voluntary positions, and their confidence in applying them in a job application. Nevertheless, valuable findings can be drawn from the survey results, particularly as students were given the opportunity to provide qualitative answers via the textbox style design for questions 3,4 and 6 .

It was hoped that a short survey would yield a high response rate but whilst all students in relevant leadership positions could participate, the response rate was low, and only included undergraduates. Potential explanations are that due to the Covid-19 pandemic students' availability, time, and capacity to prioritise such tasks may have reduced. Additionally, due to the benefits of surveys as a research tool, they are commonly used for collecting data among university students, which can result in survey fatigue (Porter et al., 2004). Another potential explanation is that students are not engaging with the concept of employability, and it is this very suspicion that prompted the research.

Despite the low response rate, the sample included representatives from all three of the selected ECA categories (sports teams, societies and network groups), and consisted of varied committee roles within these groups. Findings from this small-scale study may be hard to generalise beyond this university; however, despite the study's limitations, it is possible to draw findings from the survey results around participants' awareness of skills accrued in ECA volunteering and their confidence in articulating these skills to employers, as well as make recommendations for future research in this area, which are discussed in the following sections. 


\section{Results and discussion}

Experience in ECAs at university, particularly in leadership roles, are of great value to employers (Tchibozo, 2007; Allen et al.,, 2013). With the wide-ranging leadership opportunities available to students, this is an area that universities can harness to drive the employability of their students, and in doing so, benefit the university's ranking and reputation in league table performance; something that universities are increasingly looking to prioritise (Tymon, 2013). Findings can be drawn from the survey around motivations for volunteering in ECAs, skills and attributes acquired, and students' perceived confidence in articulating skills gained in a graduate job application. Figure 1 below indicates the number of respondents by activity, and the results demonstrated in Figures 2 - 5 are discussed in the following section.

Figure 1. Number of respondents by activity type.

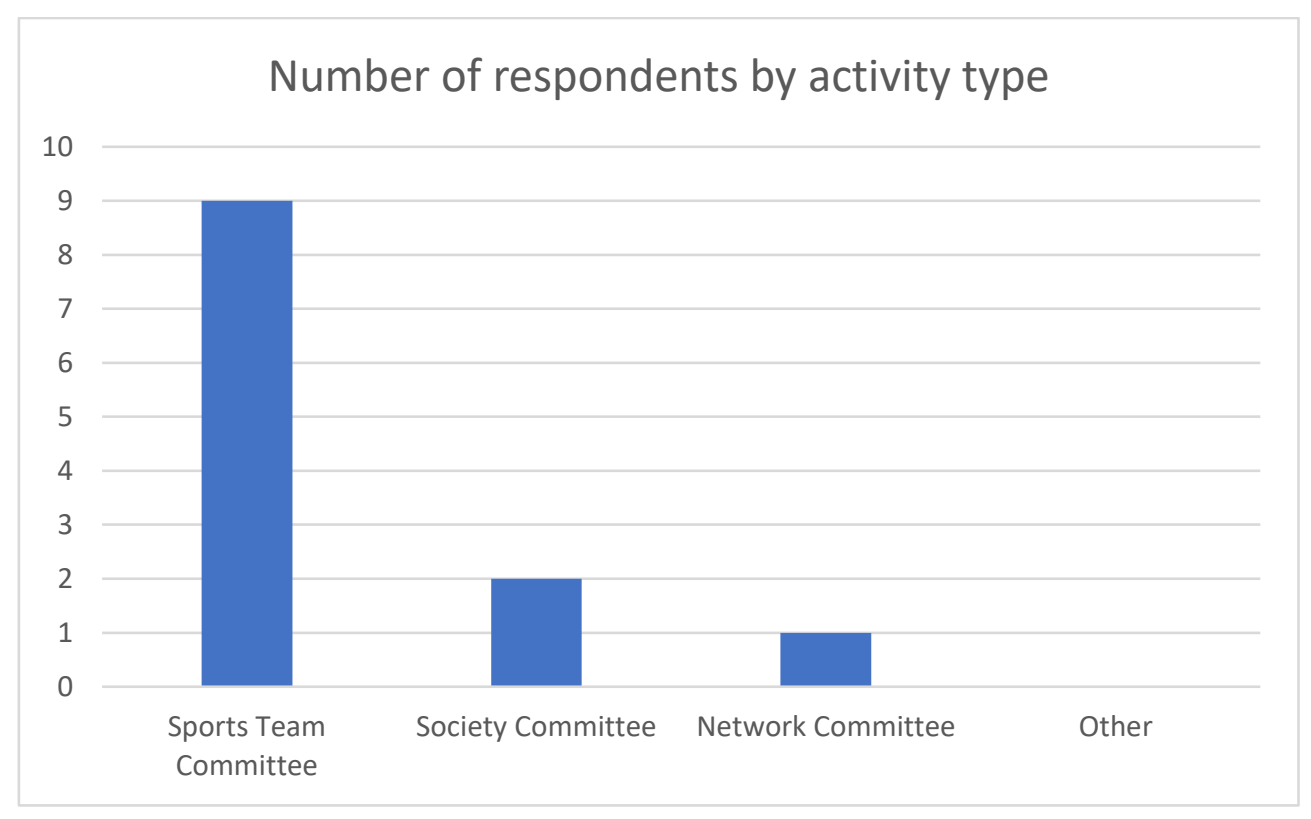

As demonstrated in Figure 2, the most common motivation that emerged from the survey was students' enjoyment or passion for their chosen activity. For instance, 'I enjoy being part of the society' and 'I love being part of a team'. The notion that enjoyment and altruism were the most common motives amongst the students for volunteering in leadership roles corroborates findings from Roulin and Bangerter's (2013) study, where most students became involved in ECAs for altruistic reasons such as interest or passion. In this study, the theme of altruism was mentioned by six participants as a key motivation for volunteering in committee roles, which is relatively unsurprising since 
helping others is implicit within the nature of some roles, such as wellbeing officer. While some respondents were motivated by wanting others to enjoy the activity, for others, it was to support the team's sustainability and development, with responses such as 'I want as many others to enjoy it as much as I did' and 'I loved the society and wanted to help it grow', demonstrating that it was important to most that they were helping others, often in varying ways.

\section{Figure 2. Motivations for volunteering in ECA.}

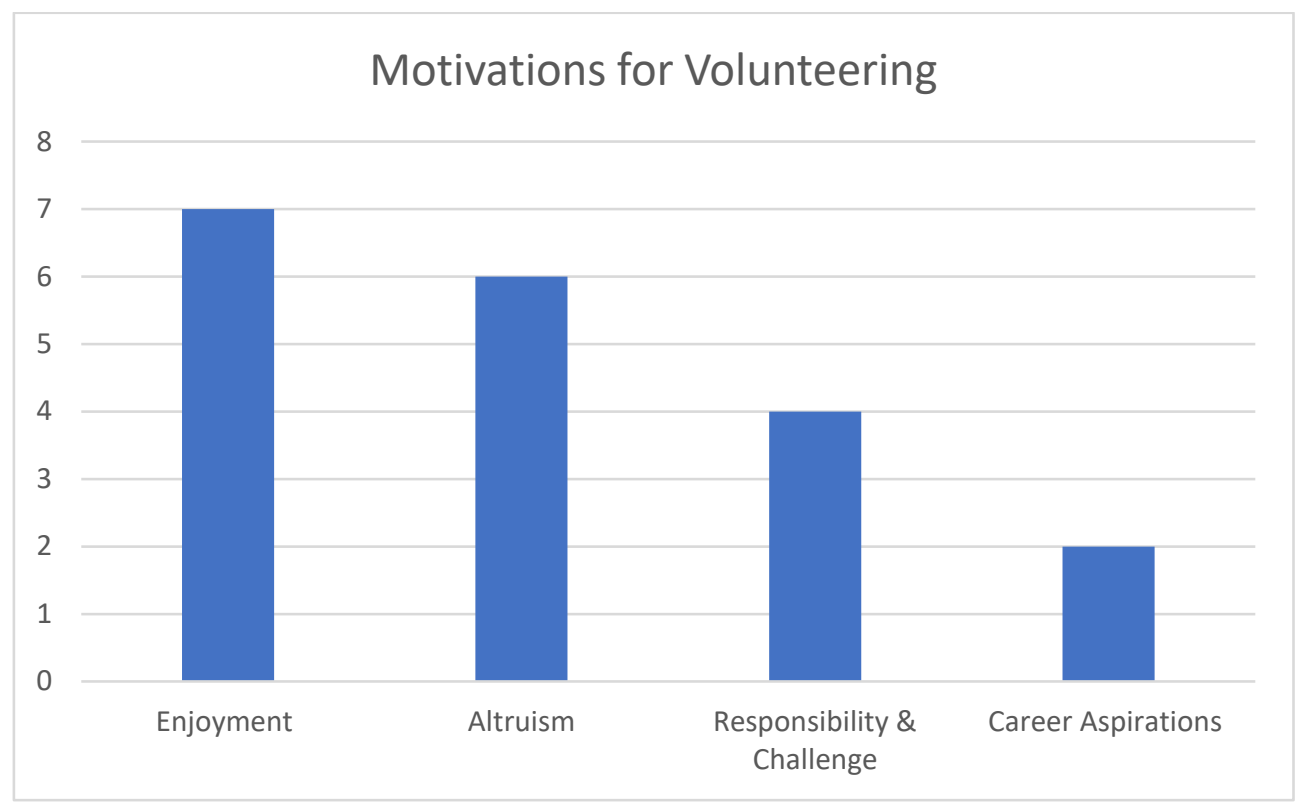

Responsibility and challenge appeared four times as another dominant motivation for ECA volunteering, demonstrated in Figure 2. Quotes such as 'I enjoy the responsibility', 'I wanted to be more involved with the decisions' and 'to challenge myself in my final year', all demonstrate positive attitudes and intrinsic motivations for their role. In addition to enjoying the responsibility, a theme that came up twice is the confidence that they would be suited to a position of leadership, for instance, 'I knew l'd be a good leader'. This demonstrates a strong mindset and someone who would be confident to take up positions of leadership in future job roles; an attitude found to be valuable to employers and demonstrates a willingness to lead (Hilliard, 2010; Tymon, 2013).

An additional motivation for volunteering in ECA committee roles is for future job aspirations or CV enhancement. With two mentions, this was the lowest reported motivation, which suggests that most students do not pursue leadership positions with career aspirations or their $\mathrm{CV}$ at the forefront of their mind. Students mostly volunteer for Journal of Learning Development in Higher Education, Issue 21: September 2021 
enjoyment, and only a small number of students in this study were primarily motivated by the potential value on their CVs which supports findings by Roulin and Bangerter (2011) and Thompson et al. (2013). However, this does not mean that students are unaware of the benefits of these leadership positions. Indeed, students are increasingly aware that having a degree will not guarantee them a job and realise they should add value to their credentials to gain advantage in the job market (Roulin and Bangerter, 2013). Participation in ECAs can be advantageous, as it allows students to demonstrate transferable skills not otherwise visible on their CV due to limited job experience (Roulin and Bangerter, 2013). The complex nature of students' motivations would benefit from further qualitative research to explore the intricacies of this issue in more depth.

\section{Figure 3: Skills gained from volunteering in ECA}

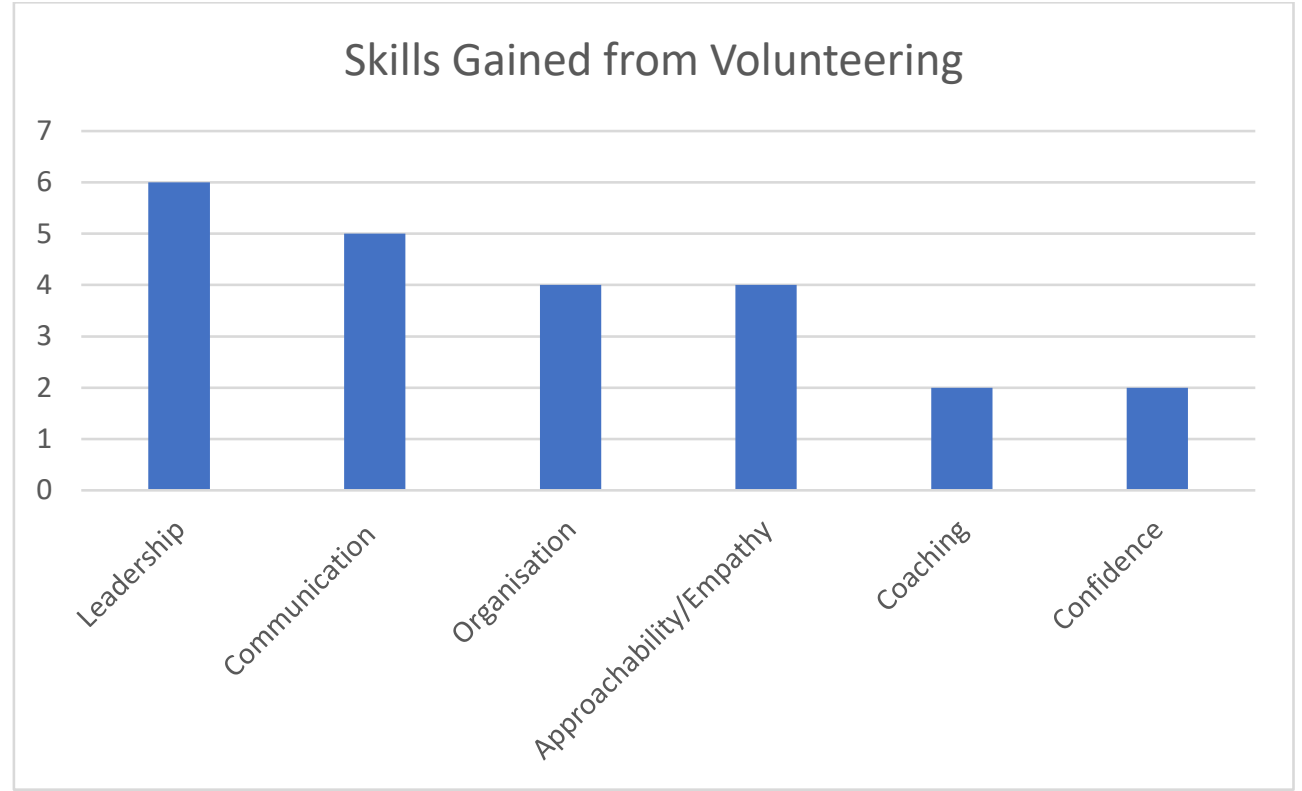

Figure 3 illustrates the skills participants identified that they had acquired from volunteering in ECAs, which are sought after traits among employers (Allen et al., 2013). Skills with two or more responses are included in Figure 3. The most frequent skill mentioned was that of leadership, receiving six mentions, which is consistent with the literature, as leadership is one of the key attributes mentioned by employers as being desirable, and developed through ECA involvement (Allen et al., 2013). Nevertheless, six mentions is relatively low considering that all twelve respondents are in some form of leadership position, even if the role of captain is perhaps more overtly related to leadership than that of a social secretary, for example. This demonstrates that this HEI could do more to raise awareness of the potential transferable skills gained from a range of voluntary positions. 
As with many attributes mentioned in the survey, leadership was often only listed. However, one respondent stated: 'leading by example when it comes to sessions and overall behaviour', which suggests awareness that leadership is important and core to their role. The notion of leading by example in sessions is noteworthy, as most sports team leaders plan and deliver training sessions at this institution, yet very few have referenced it. This is closely related to coaching, which only two respondents mentioned; the example above, and one other who stated that they gained confidence in coaching adults, from new players that have no experience in the sport to seasoned players. It is surprising that only two participants mentioned leading sessions when it is one of the core responsibilities for committee members at this university. Again, this indicates the need to raise awareness of the skills developed in the breadth of responsibilities committee members undertake at this institution.

Figure 3 illustrates that communication was another common skill identified, with five occurrences. While some listed the word, others expanded on the term and gave more detail about the way they used their communication skills in the context of their role. For example, one participant reported: 'how I communicate to my committee and also members is crucial'. This demonstrates that this respondent understands how this skill is relevant to their role and suggests that if it came to talking about their communication skills in a job application process, they would be able to articulate this.

Organisational skills are also highly valued by employers (Allen et al., 2013), and were mentioned by four participants. Once again, they simply listed the word; however, one participant stated: 'my organisation skills will come to good use', suggesting that they are thinking about the skills developed in their role in relation to future jobs or careers.

A final attribute that was mentioned frequently was approachability and empathy; one participant stated that 'being approachable for all members' was a skill they had gained and improved upon in their role. For others, this was a key part of their role, especially the welfare officers, with one participant listing 'empathy, listening, communication', demonstrating that approachability was fundamental to their role, as all three skills contribute significantly to being approachable. 
Other skills that were identified, but only mentioned once, were budget and finance, branding, teamwork, technical radio skills, socialisation, problem solving, social media and marketing and creativity. It is unsurprising that some of these skills received fewer mentions since budget and finance and social media and marketing are role-specific and would not be expected of every volunteer. The participants that did mention these attributes seemingly have a good awareness of the role-specific skills they have developed. Whilst students were not asked directly to expand on the skills gained, the fact that some provided more detailed information about these skills and gave examples suggests that they would be better equipped to articulate them in a job interview or on a CV, rather than just list them, which was identified as significant for improving employability (Allen et al., 2013).

As depicted in Figure 4, question 5 explored students' confidence in articulating their roles on applications or in interviews. Five respondents reported that they would be completely confident, while all others stated that they would be fairly confident, which shows that respondents feel reasonably confident when it comes to articulating their roles in job interviews or applications. However, some of the themes from question 6 as well as the themes from questions 3 and 4 suggest that this confidence is perhaps misplaced since they did not articulate the breadth, depth or applicability of their skills.

\section{Figure 4. Confidence in applying skills gained in a job application.}

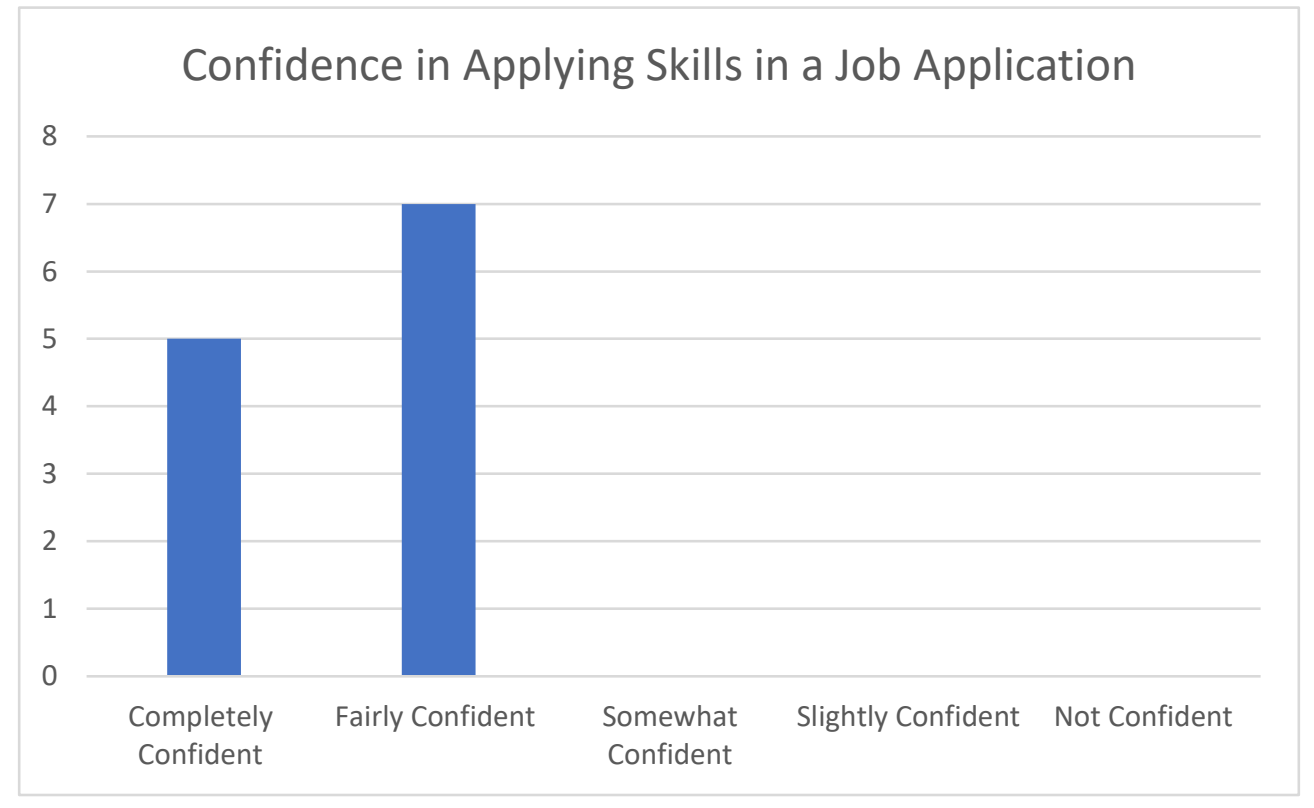

The final question was an opportunity to garner feedback from students in relation to how the university can better support students in relation to employability. While some 
respondents did not feel the need for additional help, some wanted more intervention from the university when it comes to CV writing or looking at future job prospects. Two respondents said that they had no idea about how the university could help, and a further two said that they did not think that there was anything more the university could do. Only one participant recognised the resources already available: 'I'm able to place my role on my HEAR, so other help isn't needed'. The HEAR is used by the university as a platform for students to record their ECA participation. These responses corroborate findings from question 5, as the lack of feedback or the feeling that support is not needed suggests the students are confident enough in their own ability, or that what is already available to them when it comes to career support is sufficient.

Conversely, other responses suggested some form of intervention from the university in the form of career advice or training is needed for undergraduates. This does not necessarily mean that they are not confident in articulating their role to an employer, but could suggest that they are not as confident as they say they are. Training or workshops led by staff was suggested by four people, for example: 'give us training in our role', 'go over with students the basics for a job interview' and 'show us how to explain and describe our roles professionally'. These suggestions demonstrate that they are not totally confident and that they would value some extra support from the university around employability.

Students who said they were confident also said that they would like the university to show them how to explain their role professionally, indicating they are not confident when it comes to articulating their role in a job interview or application. This is also seen in Roulin and Bangerter's (2013) study, with most students not including ECA involvement on their CVs, yet they were aware that their activities could help them demonstrate soft skills.

A final finding, depicted in Figure 5, is that the university could better communicate the ways in which voluntary ECA roles link to careers; whilst students may be confident in talking about their role, they are not as confident in applying these skills in a work context. While perhaps students were offering suggestions that would benefit others and were not necessarily offering feedback that would help them personally, conclusions drawn from the overall analysis indicate that students are not as confident as they say they are. Answers to questions five and six to an extent support this, as does the dominant finding that emerged in the literature that students/graduates do not demonstrate the relevant skills to employers 
in job applications, interviews and in the workplace itself (Frankham, 2017). Findings point to students feeling that the university could be doing more to enhance their readiness to apply for graduate level jobs.

Figure 5. What the university can do to help enhance employability.

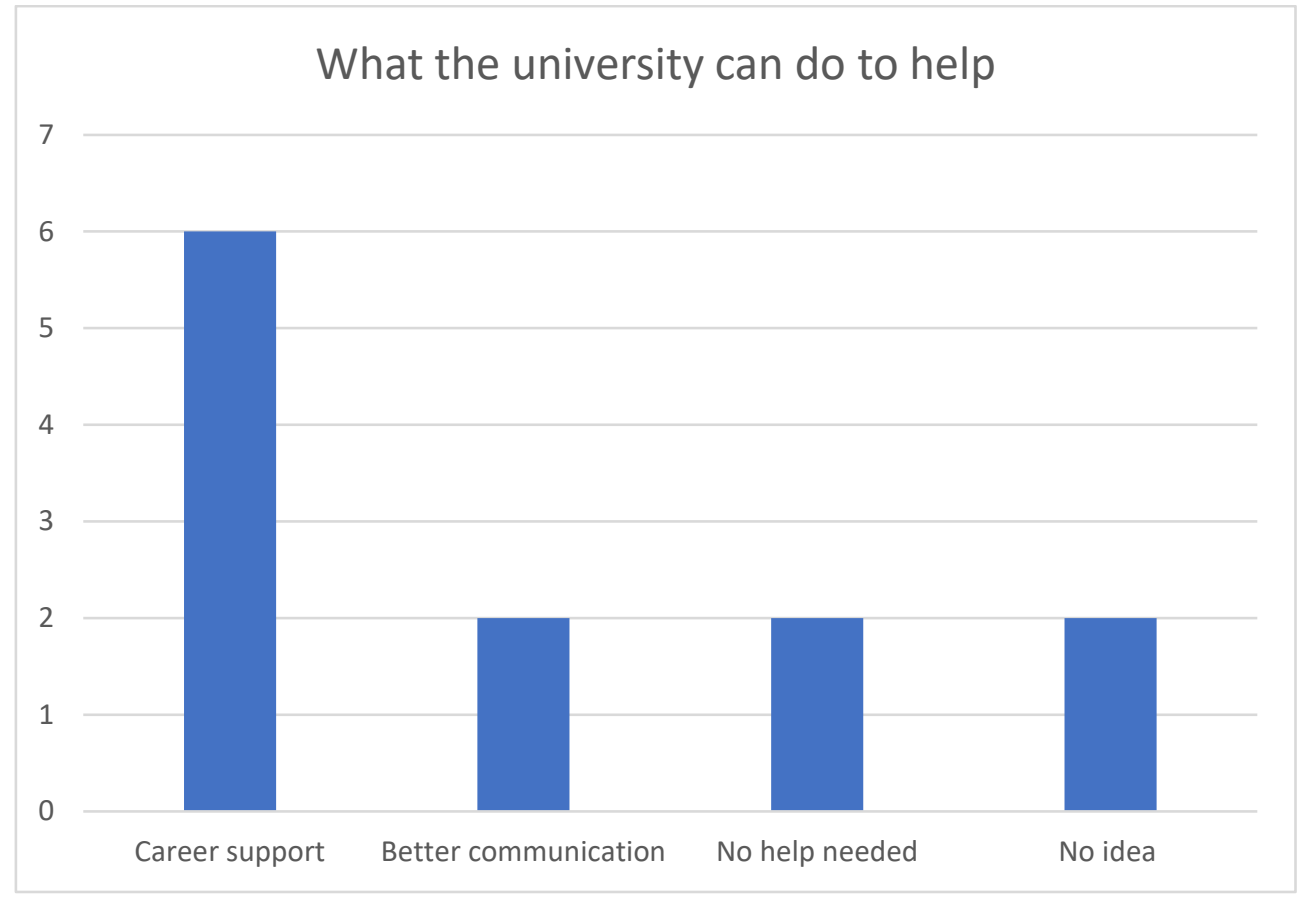

\section{Project outcome}

The research project was initiated because staff within the Centre for Student Engagement and Employability believed that the university could do more to harness the potential skills gained in voluntary ECA leadership positions to enhance employability. Conclusions drawn from the survey supported this expectation. This is particularly evident in answers to questions 4 and 6 . Therefore, a range of staff expertise was utilised to create a workshop and resource which help students to harness the potential transferability of the skills gained through volunteering in ECAs and thereby demonstrate that they are work ready in a job application process.

The workshop consists of two parts. The students receive a three-part presentation including a briefing by the Student Union's Vice President, Activities on the committee roles available and the responsibilities they entail, an overview of key academic literature 
on the interrelation between employability skills and volunteering in ECAs from an academic in Student Engagement, and some inspiring stories of alumni who have gone on to follow high achieving career paths influenced by their experiences of volunteering in ECAs whilst at the university.

The second part of the workshop is interactive; participants are given advice from a Careers Advisor on how to write a job application effectively and are then given a series of job specifications and tasked to consider how they would apply the skills gained in their voluntary roles. Time for questions and answers is made available at the end of the session for students to ask advice about specific career paths or transition from HE into the world of work. Feedback from the workshop was positive, with one student stating: 'the content was really helpful and I enjoyed it'. Another outcome of the study is that a resource has been produced identifying the range of leadership roles and their benefits in relation to employability skills, available on the university intranet and Student Union website.

\section{Conclusions}

Results indicate that although students were confident in articulating skills gained through ECA volunteering to employers, they did not identify many skills or expand on their transferability to the workplace. Findings drawn may not be representative of all universities since the university investigated is comparatively small in relation to the sector, the participants only consisted of undergraduates, and the response rate was low. Nevertheless, findings are valuable and contribute towards the growing body of literature on student employability, particularly as the study has provided a model that can be adopted by other universities on a larger scale to investigate this further. Future research should aim to conduct interviews with students to garner more detail around their awareness of the potential skills gained through volunteering in ECA positions and to discuss their confidence in drawing on them to demonstrate employability. Finally, it is also recommended that, using this model, research could be conducted on a larger scale, and by comparing different institutions, it would be possible to draw more generalisable findings around enhancing employability through voluntary committee roles at university. 


\section{References}

Allen, K., Bullough, S., Cole, D., Shibli, S. and Wilson, J. (2013) The impact of engagement in sport on graduate employability. Available at: http://hdl.voced.edu.au/10707/260938 (Accessed: 21 May 2021).

Bowers-Brown, T. and Harvey, L. (2004) 'Are there too many graduates in the UK?: a literature review and an analysis of graduate employability', Industry and Higher Education, 18(4), pp.243-254. Available at: https://doi.org/10.5367\%2F0000000041667538 (Accessed: 26 May 2021).

Branine, M. (2008) 'Graduate recruitment and selection in the UK: a study of recent changes in methods and expectations', Career Development International, 13(6), pp.497-513. Available at: https://doi.org/10.1108/13620430810901660 (Accessed: 26 May 2021).

Braun, V. and Clarke, V. (2012) 'Thematic analysis', in Cooper, H., Camic, P.M., Long, D.L., Panter, A.T., Rindskopf, D. and Sher, K.J. (eds.) APA handbook of research methods in Psychology: quantitative, qualitative, neuropsychological, and biological. research designs, (Volume 2). Washington DC: American Psychological Association. Available at: https://doi.org/10.1037/13620-004 (Accessed: 22 May 2021).

Christians, C.G. (2011) 'Ethics and politics in qualitative research', in Denzin, N.K. and Lincoln, Y.S. (eds.) The Sage handbook of qualitative research. 4th edn. Thousand Oaks, CA: Sage.

Clark, G., Marsden, R., Whyatt, J. D., Thompson, L., and Walker, M. (2015) 'II's everything else you do...": alumni views on extracurricular activities and employability', Active Learning in Higher Education, 16(2), pp.133-147. Available at: https://doi.org/10.1177/1469787415574050 (Accessed: 22 May 2021).

Clarke, M. (2018) 'Rethinking graduate employability: the role of capital, individual attributes and context', Studies in Higher Education, 43(11), pp.1923-1937. 
Available at: https://doi.org/10.1080/03075079.2017.1294152 (Accessed: 16 May 2021).

Creswell, J.W. and Clark, V.L.P. (2018) Designing and conducting mixed methods research. London: Sage.

Cumming, J. (2010) 'Contextualised performance: reframing the skills debate in research education', Studies in Higher Education, 35(4), pp.405-419. Available at: https://doi.org/10.1080/03075070903082342 (Accessed: 22 May 2021).

Donald, W.E., Ashleigh, M.J. and Baruch, Y. (2018) 'Students' perceptions of education and employability: facilitating career transition from higher education into the labor market', Career Development International, 23(5), pp.513-540. Available at: https://doi.org/10.1108/CDI-09-2017-0171 (Accessed: 26 May 2021).

Flick, U. (2007) 'Concepts of triangulation', in Flick, U. (ed.) Managing quality in qualitative research. London: SAGE Publications, Ltd.

Fowler, F.J. (2014) Survey research methods. $5^{\text {th }}$ edn. London: Sage.

Frankham, J. (2017) 'Employability and higher education: the follies of the "productivity challenge" in the Teaching Excellence Framework', Journal of Education Policy, 32(5), pp.628-641. Available at: https://doi.org/10.1080/02680939.2016.1268271 (Accessed: 22 May 2021).

Gedye, S. and Beaumont, E. (2018) “"The ability to get a job”: student understandings and definitions of employability', Education + Training, 60(5), pp.406-420. Available at: https://doi.org/10.1108/ET-10-2017-0159 (Accessed: 22 May 2021).

Griffiths, K., Bullough, S., Shibli, S. and Wilson, J. (2017) 'The impact of engagement in sport on graduate employability: implications for higher education policy and practice', International Journal of Sport Policy and Politics, 9(3), pp.431-451. Available at: https://doi.org/10.1080/19406940.2017.1359648 (Accessed: 22 May 2021). 
Heaton, N., McCracken, M. and Harrison, J. (2008) 'Graduate recruitment and development: sector influence on a local market/regional economy', Education + Training, 50(4), pp.276-288. Available at: https://doi.org/10.1108/00400910810880524 (Accessed: 22 May 2021).

Hesketh, A.J. (2000) 'Recruiting an elite? Employers' perceptions of graduate education and training', Journal of Education and Work, 13(3), pp.245-271. Available at: https://doi.org/10.1080/713676992 (Accessed: 22 May 2021).

Hilliard, A.T. (2010) 'Student leadership at the university', Journal of College Teaching \& Learning, 7(2), pp.93-98. Available at: https://doi.org/10.19030/tlc.v7i2.93 (Accessed: 22 May 2021).

Jackson, N. (2011) 'Recognising a more complete education through a Lifewide Learning Award', Higher Education, Skills and Work-Based Learning, 1(3), pp.247-261. Available at: https://doi.org/10.1177/1469787415574050 (Accessed: 22 May 2021).

Lackner, C. and Martini, T. (2017) 'Helping university students succeed at employment interviews: the role of self-reflection in e-portfolios', Teaching \& Learning Inquiry, 5(2), pp.3-15. Available at: http://dx.doi.org/10.20343/teachlearninqu.5.2.2 (Accessed: 22 May 2021).

Lowden, K., Hall, S., Elliot, D. and Lewin, J. (2011) Employers' perceptions of the employability skills of new graduates. Available at:

https://www.educationandemployers.org/wpcontent/uploads/2014/06/employability skills as pdf - final online version.pdf (Accessed: 26 May 2021).

McCaig, C. (2011) 'Access agreements, widening participation and market positionality: enabling student choice?', in Molesworth, M., Scullion, R. and Nixon, E. (eds.) The marketisation of higher education and student as consumer. Abingdon: Routledge. 
Milburn-Shaw, H. and Walker, D. (2017) 'The politics of student engagement', Politics, 37(1), pp.52-66. Available at: https://doi.org/10.1177/0263395715626157 (Accessed: 22 May 2021).

Office for Students (2020) About the TEF. Available at:

https://www.officeforstudents.org.uk/advice-and-guidance/teaching/about-the-tef/ (Accessed: 21 May 2021).

Oliver, B. (2015) 'Redefining graduate employability and work-integrated learning: proposals for effective higher education in disrupted economies', Journal of Teaching and Learning for Graduate Employability, 6(1), pp.56-65. Available at: http://dx.doi.org/10.21153/jtlge2015vol6no1art573 (Accessed: 22 May 2021).

Porter, S.R., Whitcomb, M.E. and Weitzer, W.H. (2004) 'Multiple surveys of students and survey fatigue', New Directions for Institutional Research, (121), pp.63-73. Available at: https://doi.org/10.1002/ir.101 (Accessed: 22 May 2021).

Prospects (2018) Graduate unemployment rate lowest in 39 years as skills shortages boost prospects. Available at: https://www.prospects.ac.uk/prospects-pressoffice/graduate-unemployment-rate-lowest-in-39-years-as-skills-shortages-boostprospects (Accessed 21 May 2021).

Roulin, N. and Bangerter, A. (2013) 'Students' use of extra-curricular activities for positional advantage in competitive job markets', Journal of Education and Work, 26(1), pp.21-47. Available at: http://dx.doi.org/10.1080/13639080.2011.623122 (Accessed: 21 May 2021).

Stevenson, J. and Clegg, S. (2011) 'Possible selves: students orientating themselves towards the future through extracurricular activity', British Educational Research Journal, 37(2), pp.231-246. Available at: https://doi.org/10.1080/01411920903540672 (Accessed: 22 May 2021).

Tchibozo, G. (2007) 'Extra-curricular activity and the transition from higher education to work: a survey of graduates in the United Kingdom', Higher Education Quarterly, 
6(1), pp.37-56. Available at: http://dx.doi.org/10.1111/j.1468-2273.2006.00337.x (Accessed: 22 May 2021).

Teng, W., Ma, C., Pahlevansharif, S. and Turner, (2019) 'Graduate readiness for the employment market of the 4th industrial revolution: the development of soft employability skills', Education + Training, 61(5), pp.590-604. Available at: https://doi.org/10.1108/ET-07-2018-0154 (Accessed: 22 May 2021).

Thompson L.J., Clark, G., Walker, M. and Whyatt, J.D. (2013) '"It's just like an extra string to your bow": exploring higher education students' perceptions and experiences of extracurricular activity and employability', Active Learning in Higher Education, 14(2), pp.135-147. Available at: https://doi.org/10.1177/1469787413481129 (Accessed: 22 May 2021).

Tieu, T.T., Pancer, S.M., Pratt, M.W., Wintre, M.G.,Birnie-Lefcovitch, S.,Polivy, J. and Adams, G. (2010) 'Helping out or hanging out: the features of involvement and how it relates to university adjustment' Higher Education, 60(3), pp.343-355. Available at: http://dx.doi.org/10.1007/s10734-009-9303-0 (Accessed: 22 May 2021).

Tymon, A. (2013) 'The student perspective on employability', Studies in higher education, 38(6), pp.841-856. Available at: https://doi.org/10.1080/03075079.2011.604408 (Accessed 26 May 2021).

Winstone, N., Balloo, K., Gravett, K., Jacobs, D. and Keen, H. (2020) 'Who stands to benefit? Wellbeing, belonging and challenges to equity in engagement in extracurricular activities at university', Active Learning in Higher Education, 16(2), pp.133-147. Available at: https://doi.org/10.1177/1469787420908209 (Accessed: 16 May 2021).

\section{Author details}

Maria Moxey is a Teaching Fellow in Student Engagement in Higher Education. Prior to teaching, her professional background was in university sport, having worked at the 
University of Winchester and the University of Brighton. Maria's research interests include sport, identity and belonging in higher education.

Edward Simpkin is a Student Opportunities Researcher in a Research Associate role at the University of Winchester. His educational background is in history, and he was involved in a vast array of extra-curricular activities during his time as an undergraduate student. 